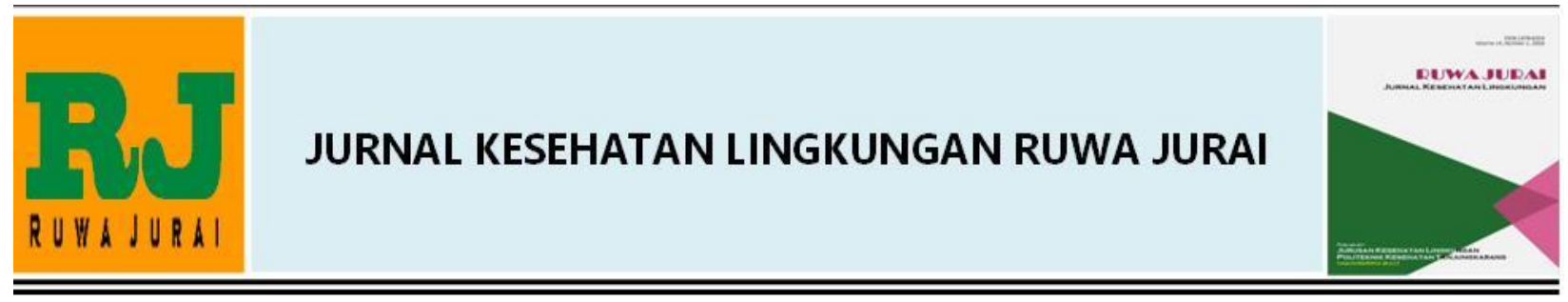

\title{
PENGARUH KEBISINGAN, UMUR, MASA KERJA, LAMA PAPARAN DAN PENGGUNAAN ALAT PELINDUNG TELINGA PADA TENAGA KERJA DI PERUSAHAAN KABEL OTOMOTIF
}

\author{
Mahesi Yustika Abjasiqo ${ }^{1}$, Winarko, Winarko ${ }^{2 *}$, Ernita Sari ${ }^{3}$ \\ 1,2,3 Department of Environmental Health, Poltekkes Kemenkes Surabaya
}

\section{Artikel Info : \\ Received 21 September 2020 Accepted 30 Desember 2020 Available online 31 Desember 2020}

Editor: Mei Ahyanti

Key word :

Noise, worker characteristics, safety

Kata Kunci :

Kebisingan, karakteristik pekerja, $K 3$

Ruwa Jurai: Jurna

Kesehatan Lingkungan is licensed under a Creative Commons

Attribution-NonCommercial 4.0 International License.

\begin{abstract}
PT. Indowire Prima Industrindo is a company that manufactures copper automotive cables. In the operational process, it causes noise to reach 79-103 dBA. The study was conducted to obtain an overview of risk factors in the production section, namely age, years of service, duration of exposure, and use of PPE. The study used an observational research design with a descriptive study method, with a total sample of 62 people chooses randomly. Data collected through interviews, observations, and measurements. The results of research at PT. Indowire found that only $21 \%$ of qualified workplace noise. Most workers (93.5\%) are older than 40 years old and have a working period of more than 10 years of $22.6 \%$. All workers in the production section get noise exposure for 7 hours/day, and $21 \%$ do not use PPE. This study of noise indicates a high risk for hearing loss. There is a need for technical control efforts, the implementation of a work rotation system, training on APT, as well as providing strict supervision and policies for workers who do not use APT in noisy workplaces.
\end{abstract}

PT. Indowire Prima Industrindo adalah perusahaan yang memproduksi kabel otomotif tembaga. Pada proses operasionalnya, menimbulkan kebisingan hingga mencapai 79-103 dBA. Penelitian dilakukan untuk mendapatkan gambaran faktor risiko di bagian produksi, yaitu umur, masa kerja, lama paparan dan penggunaan APT. Penelitian menggunakan desain observasional dengan metode studi deskriptif, dengan jumlah sampel sebanyak 62 orang yang dipilih secara random. Data dikumpulkan melalui wawancara, observasi dan pengukuran. Hasil penelitian di PT. Indowire mendapatkan bahwa kebisingan tempat kerja yang memenuhi syarat hanya $21 \%$. Sebagian besar pekerja (93.5\%) berumur lebih dari 40 tahun, dan memiliki masa kerja lebih dari 10 tahun sebesar $22.6 \%$. Seluruh pekerja di bagian produksi mendapatkan paparan kebisingan selama 7 jam/hari, dan sebesar 21\% tidak menggunakan Alat Pelindung Telinga (APT). Hasil penelitian menunjukkan kebisingan memiliki risiko yang tinggi untuk mengalami gangguan pendengaran. Perlu upaya pengendalian teknis, penerapan sistem rotasi kerja, pelatihan tentang $A P T$, serta memberikan pengawasan dan kebijakan yang ketat pada pekerja yang tidak menggunakan APT di tempat kerja yang bising.

* Corresponding author: Winarko, Winarko

Prodi Sanitasi Lingkungan Poltekkes Kemenkes Surabaya

Jl. Pucang Jajar Tengah No.56, Kertajaya, Kec. Gubeng, Kota Surabaya, Jawa Timur 60282.

Email:winarko0202@gmail.com

\section{PENDAHULUAN}

Pada era modern, hampir semua pekerjaan telah dibantu oleh alat-alat yang dapat memudahkan pekerjaan, seperti mesin untuk meningkatkan produktivitas sehingga memberikan keuntungan yang lebih besar. Namun, penggunaan mesin juga dapat memberi kerugian bagi penggunanya. Kebisingan di tempat kerja merupakan salah satu kerugian akibat penggunaan mesin (Pratama, 2018).

Kebisingan adalah suara yang tidak dikehendaki oleh manusia dan berpengaruh negatif terhadap kesehatan (Dewanty, 2015). Berdasarkan Permenkes RI No 70 tahun 2016, Nilai Ambang Batas (NAB) kebisingan merupakan nilai yang mengatur tentang tekanan 
bising rata-rata atau level kebisingan berdasarkan durasi pajanan bising yang mewakili kondisi dimana hampir semua pekerja terpajan bising berulang-ulang tanpa menimbulkan gangguan pendengaran dan memahami pembicaraan normal. NAB kebisingan yang diatur dalam peraturan ini tidak berlaku untuk bising yang bersifat impulsif atau dentuman yang lamanya $<3$ detik. NAB kebisingan di tempat kerja, ditetapkan sebesar 85 dBA. Pajanan bising tidak boleh melebihi $140 \mathrm{dBA}$ walaupun hanya sesaat.

Pada kebisingan 85 dBA, pekerja diperbolehkan terpapar selama 8 jam per hari atau 40 jam perminggu.(kementerian kesehatan, 2016) Kebisingan bisa memberi dampak auditori (gangguan ambang pendengaran) dan dampak non auditori (gangguan komunikasi, ancaman bahaya keselamatan, menurunnya performa kerja, stress dan kelelahan). Pengaruh utama kebisingan pada kesehatan adalah kerusakan pada indera pendengaran yang berujung pada ketulian (Dewanty, 2015).

Data World Health Organization (WHO) menyebutkan 360 juta orang atau 5,2\% di seluruh dunia memiliki gangguan pendengaran, sebagian besar terjadi di negara berpenghasilan rendah dan menengah, termasuk Indonesia. Saat ini, Indonesia merupakan negara peringkat 4 di Asia untuk angka ketulian tertinggi setelah Sri Lanka, Myanmar, dan India (Darmawan, 2013). Data Litbang Kemenkes RI menunjukkan bahwa sebanyak 2,6\% penduduk Indonesia berumur di atas 5 tahun mengalami gangguan pendengaran, sebanyak 0,09\% mengalami ketulian, 18,8\% ada sumbatan serumen, dan $2,4 \%$ ada sekret di liang telinga. Angka ini terus meningkat akibat akses ke pelayanan yang belum optimal. Data tersebut juga menyebutkan 9 provinsi di Indonesia yang mengalami gangguan ambang pendengaran yaitu di Provinsi DIY, Sulawesi Barat, Jawa Timur, Maluku Utara, Sumatera Selatan, Sulawesi Selatan, Jawa Tengah, Lampung dan NTT (Kemenkes RI, 2017).

Hasil Penelitian Ibrahim (2016) di PT. Japfa Comfeed Tahun 2016 mendapatkan hubungan antara intensitas kebisingan, lama kerja, masa kerja, umur pekerja, dan pemakaian Alat Pelindung Telinga (APT) dengan keluhan gangguan pendengaran pada tenaga kerja bagian produksi. Penelitian Alda Chelsia di PT.
PAL Indonesia Surabaya dengan hasil kebisingan >85 $\mathrm{dB}(\mathrm{A})$ menunjukkan adanya hubungan antara kebisingan terhadap ambang pendengaran karena berdasarkan hasil uji ambang pedengaran, pekerja yang memiliki ambang pendengaran tidak normal sebesar $38,9 \%$ dan pekerja yang pendengarannya normal sebesar 61,1\% (Ibrahim, 2016).

PT. Indowire Prima Industrindo adalah perusahaan swasta yang memproduksi kabel otomotif dari tembaga berlokasi di J. Margomulyo Indah C-1, Tandes Surabaya. PT. Indowire Prima Industrindo dalam proses produksinya menggunakan mesin-mesin yang menimbulkan kebisingan. Suara yang dihasilkan dapat mengganggu pekerja saat melakukan pekerjaannya. Jika paparan bising terjadi dalam waktu lama, maka akan menimbulkan gangguan bagi pekerja dan akan mempengaruhi produktifitas (Qatrunnada, 2019).

Hasil observasi pada studi pendahuluan mendapatkan nilai intensitas kebisingan di bagian produksi di PT. Indowire Prima Industrindo (RBD, MWD, Bunching, Extruder, Tubular, PPIC, Crusher, VT/COT) sebesar 79-103 dBA. Hasil wawancara dengan pekerja diperoleh hasil bahwa sebanyak 3 dari 10 pekerja tidak menggunakan Alat Pelindung Telinga (APT), 4 dari 10 pekerja berumur lebih dari 40 tahun dan telah bekerja lebih dari 10 tahun, dan pekerja mengalami paparan bising selama 8 jam setiap harinya.

Berdasarkan hasil studi pendahuluan, penelitian bertujuan untuk mendapatkan gambaran tingkat kebisingan, umur, masa kerja, lama paparan dan penggunaan APT pada pekerja di area produksi PT. Indowire Prima Industrindo.

\section{METODE}

Penelitian menggunakan desain penelitian observasional dengan metode studi deskriptif. Jumlah pekerja yang berpartisipasi pada penelitian ini sebanyak 62 orang yang dipilih secara random pada setiap unit di bagian produksi, yaitu unit $R B D, M W D$, Bunching, Extruder, Tubular, PPIC, Crusher, VT/COT. Menggunakan tingkat kepercayaan 95\%, maka jumlah sampel minimal pada penelitian telah terpenuhi. 
Pengumpulan data dilakukan dengan mewawancarai pekerja yang terpilih sebagai sampel, mengamati/observasi cara kerja dan penggunaan APT, serta melakukan pengukuran intensitas kebisingan di setiap unit kerja. Selanjutnya, data dikelompokkan menjadi dua kategorik pada setiap variabel.

\section{HASIL}

Pengukuran kebisingan dilakukan pada setiap lokasi unit kerja bagian produksi PT. Indowire Prima Industrindo. Hasil pengukuran menujukkan bahwa mayoritas pekerja (79\%) melakukan pekerjaaannya pada area dengan tingkat kebisingan yang tidak memenuhi syarat (Tabel 1). Berdasarkan umur, sebagian besar pekerja (93.5\%), berumur maksimal 40 tahun.

Tabel 1. Gambaran Variabel Penelitian

\begin{tabular}{llll}
\hline Variabel & & F & $\%$ \\
\hline Kebisingan & Memenuhi syarat $(<85 \mathrm{dBA})$ & 13 & 21 \\
& Tidak memenuhi syarat $(>85 \mathrm{dBA})$ & 49 & 79 \\
\multirow{2}{*}{ Umur } & $\leq 40$ Tahun & 58 & 93,5 \\
\multirow{2}{*}{ Masa kerja } & $>$ 40 Tahun & 4 & 6,5 \\
\multirow{2}{*}{ Lama paparan } & $\leq$ 10 Tahun & 48 & 77,4 \\
\multirow{2}{*}{ Penggunaan APT } & > 10 Tahun & 14 & 22,6 \\
& 7 Jam/hari & 62 & 100 \\
& Memakai & 0 & 0 \\
& Tidak memakai & 49 & 79 \\
\hline
\end{tabular}

Pada Tabel 1 terlihat bahwa sebagian besar pekerja $(77,4 \%)$ memiliki masa kerja kurang dari 10 tahun. Berdasarkan lamanya paparan, seluruh pekerja terpapar kebisingan selama 7 jam/hari, sebanyak $21 \%$ pekerja tidak menggunakan APD saat bekerja.

\section{PEMBAHASAN}

1. Kebisingan

Kebisingan adalah semua bunyi atau suara yang tidak dikehendaki yang dapat mengganggu kesehatan dan keselamatan (Anizar, 2009). Berdasarkan jenisnya, kebisingan di area produksi PT. Indowire Prima Industrindo termasuk kebisingan kontinyu (steady state). Kebisingan kontinyu adalah suara bising yang berlangsung terus menerus dimana fluktuasi intensitasinya tidak lebih dari $6 \mathrm{dBA}$ (Sumarna, 2018).

Hasil penelitian mendapatkan bahwa mayoritas pekerja terpapar kebisingan dengan intensitas di atas $85 \mathrm{dBA}$. Apabila terus dibiarkan, maka akan berpengaruh pada pekerja. Menurut Irzal (2016) pengaruh utama dari kebisingan pada pekerja adalah kerusakan indera pendengaran yang menyebabkan ketulian. Maka dari itu, perlu adanya pengendalian terhadap kebisingan yang tidak memenuhi syarat. Pengendalian kebisingan di tempat kerja terdiri dari pengendalian secara teknis, administratif dan penggunaan alat pelindung diri (Irzal, 2016).

Pengendalian kebisingan yang dapat dilakukan untuk mengurangi kebisingan di bagian produksi PT. Indowire Prima Industrindo adalah pengendalian secara teknis, antara lain melakukan perbaikan dan perawatan dengan mengganti bagian yang bersuara dan melumasi semua bagian yang bergerak, menambah sekat dengan bahan yang cepat menyerap bising, mengisolasi peralatan dengan cara menjauhkan sumber dari pekerja, menutup mesin ataupun membuat barrier/penghalang. Pengendalian secara teknis yang telah dilakukan di PT. Indowire Prima Industrindo yaitu pengecekan rutin yang dilakukan 2 minggu sekali. Apabila terdapat alat yang rusak, maka dilakukan pengecekan khusus.

\section{Umur}

Seseorang yang bertambah umurnya akan mengalami penurunan daya dengar secara progresif dan bertahap. Pada umumnya seseorang yang berumur di atas 40 tahun akan mengalami penurunan kemampuan pendengaran (Putri, 2016). Bertambahnya umur 
menyebabkan membran yang terletak pada bagian telinga tengah dan telinga dalam, banyak yang mengalami kerusakan (Marpaung, 2018). Namun seseorang yang berumur $\leq 40$ tahun juga dapat mengalami penurunan kualitas ambang pendengaran apabila sering terpapar kebisingan yang melebihi NAB.

Berdasarkan hasil penelitian, didapat responden yang mengalami gangguan pendengaran, baik yang berumur kurang dari 40 tahun maupun pekerja yang berumur di atas 40 tahun. Seseorang yang berumur 40 tahun akan mengalami penurunan ambang pendengaran sebesar 0,05 dB setiap penembahan umur 1 tahun (Wibowo, 2012). Hal tersebut kemungkinan disebabkan kebisingannya yang tidak memenuhi syarat sehingga mempengaruhi ambang pendengaran pekerjannya. Disarankan pada perusahaan untuk membatasi paparan kebisingan pada tenaga kerja yang berumur > 40 tahun. Sehingga pengendalian yang tepat dalam hal ini adalah pengendalian secara administratif, yaitu penerapan rotasi kerja dari satu bagian ke bagian yang lain untuk mengurangi paparan kebisingan pada pekerja (Irzal, 2016).

\section{Masa Kerja}

Berdasarkan tabel 1 dapat terlihat bahwa sebagian besar pekerja di bagian produksi PT. Indowire Prima Industrindo memiliki masa kerja $\leq 10$ tahun (77,4\%). Tenaga kerja yang terpapar oleh kebisingan kontinyu maupun terputus putus selama 10-15 tahun memiliki risiko mengalami gangguan pendengaran. Sehingga dapat disimpulkan bahwa semakin lama masa kerja, semakin besar risiko pekerja untuk mengalami gangguan pendengaran (Syah, 2016).

Berdasarkan data tersebut, perlu dilakukan pengendalian untuk mencegah semakin meningkatnya gangguan kesehatan pendengaran pada pekerja. Selain melakukan pengendalian secara teknis, pengendalian yang dapat dilakukan berkaitan dengan masa kerja adalah secara administratif. Penerapan sistem rotasi kerja seperti mengganti posisi pekerja dari tempat kerja yang bising ke tempat yang tidak bising, membatasi pekerja yang telah bekerja di tempat bising diatas 5 tahun, serta pembagian shift kerja. Ketulian bersifat progresif, yaitu pada awalnya bersifat sementara tetapi bila bekerja terus menerus di tempat bising akan berakibat pada hilangnya daya dengar secara menetap atau tuli (Buchari, 2007).

\section{Lama Paparan}

Berdasarkan Tabel 1, lama paparan pekerja di bagian produksi PT. Indowire Prima Industrindo tahun 2020, seluruhnya memiliki lama paparan 7 jam (100\%). Menurut Peraturan Menteri Ketenagakerjaan Republik Indonesia No. 05 Tahun 2018 tentang Keselamatan dan Kesehatan Kerja, lama bekerja dengan dengan paparan kebisingan 85dBA maksimal selama 8 jam kerja per hari. Pada penelitian ini diketahui bahwa intensitas kebisingan pada PT. Indowore Prima Industrindo melebihi NAB kebisingan (85dBA), sehingga dengan waktu kerja 7 jam/hari telah memberikan efek gangguan pendengaran.

Pengendalian yang dapat dilakukan adalah secara administratif, dengan menerapkan rotasi kerja pada pekerja yang terpapar kebisingan dengan intensitas tinggi ke tempat lain yang lebih rendah, penggunaan APT (ear muff dan ear plug) dan melakukan penyuluhan tentang bahaya kebisingan dan pentingnya penggunaan APT (Putri, 2019).

\section{Penggunaan APT}

Pada Tabel 1 terlihat bahwa proporsi pekerja pada bagian produksi PT. Indowire Prima Industrindo yang memakai APT sebanyak $79 \%$. Penggunaan APT sangat berpengaruh terhadap kesehatan pekerja melalui ambang pendengaran. APT berupa ear plug dapat mengurangi intensitas kebisingan sampai $20 \mathrm{dBA}$, sedangkan ear muff dapat mengurangi intensitas suara sampai 30 dBA (Khakim, 2011). Kekurangan dalam penelitian ini adalah pengecekan kualitas setiap APT apakah masih layak dipakai atau tidak. PT. Indowire Prima Industrindo juga harus memperhatikan tentang kualitas APT yang ada di bagian produksi. Sehingga perusahaan mengetahui apakah APT yang tersedia memenuhi syarat atau tidak memenuhi syarat. Beberapa syarat yang harus dipenuhi oleh APT menurut Anizar (2009) antara lain efektivitasnya telah teruji oleh badan yang berwenang, harus disesuaikan dengan masing-masing pekerja, harus ada sosialisasi tentang cara pemakaian APT, dilakukan pemeriksaan APT secara berkala 
untuk memastikan bahwa APT masih layak digunakan. Apabila syarat tersebut terpenuhi, maka APT dapat mereduksi kebisingan hingga angka yang aman yaitu $70-85 \mathrm{dBA}$.

Pada penelitian ini masih didapati beberapa pekerja yang tidak menggunakan APT pada saat bekerja. Tidak nyaman dipakai serta mengganggu komunikasi antar pekerja, menjadi alasan pekerja memilih untuk tidak menggunakan APT. Berdasarkan hasil pengamatan, pihak K3 Indowire telah melakukan pengawasan lapangan setiap 3 kali seminggu, namun tidak ada tindak lanjut bagi pekerja yang tidak memakai alat pelindung telinga. Apabila dibiarkan dapat berdampak pada ambang pendengaran pekerja (Rahmawati,2015).

Pengendalian gangguan pendengaran pada pekerja dapat dilakukan dengan cara memberikan penyuluhan dan pelatihan tentang alat pelindung telinga. Meningkatnya pengetahuan pekerja tentang APT, diharapkan akan meningkatkan kesadaran pekerja untuk menggunakan APT selama bekerja. Selain itu, perusahaan juga harus melakukan pengawasan serta memberikan sanksi pada pekerja yang tidak menggunakan APT. Pengawasan dapat mencegah gangguan pendengaran akibat kebisingan, sedangkan sanksi dapat membuat pekerja memperhatikan kesehatannya saat bekerja (Eryani, 2016).

\section{SIMPULAN}

Penelitian ini mendapatkan intensitas kebisingan di tempat kerja sebesar $103 \mathrm{dBA}$, dan melebihi NAB (85 dBA) yang diperkenankan. Masih terdapat pekerja yang tidak menggunakan alat pelindung telinga (21\%). Diperlukan upaya pengendalian secara teknis dengan cara melakukan perbaikan, perawatan peralatan, menambah peredam; serta melakukan pengendalian secara administratif seperti menerapkan sistem rotasi kerja, meningkatkan pengetahuan, dan pengawasan penggunaan APT.

\section{DAFTAR PUSTAKA}

Anizar. 2009, Teknik Keselamatan dan Kesehatan Kerja di Industri. Yogyakarta: Graha IImu.

Buchari. 2007. Kebisingan Industri dan Hearing Conservation Program.Medan: Universitas Sumatra Utara.
Darmawan, Very. 2013. Hubungan Karakteristik Individu Dengan Nilai Ambang Dengar Pada Tenaga Kerja Pt Bangun Sarana Baja Gresik (Studi Di Gudang 4 Dan 5 Pt Bangun Sarana Baja Gresik). Surabaya: Universitas Airlangga

Dewanty, Rindy. Astike, Sudarmaji, 2015. Analisis Dampak Intensitas Kebisingan Terhadap Gangguan Pendengaran Petugas Laundry. Surabaya: Jurnal Departemen Kesehatan Lingkungan Fakultas Kesehatan Masyarakat Universitas Airlangga,

Eryani, Yesti Mulia, 2016. Hubungan Intensitas Kebisingan, Durasi Paparan, dan Penggunaan Alat Pelindung Diri Dengan Gangguan Pendengaran Akibat Bising Pada Karyawan PT. Bukit Asam (Persero) Tbk Bandarlampung. Bandar Lampung: Universitas Lampung Journal of Chemical Information and Modeling, 53(9), 1689-1699.

Ibrahim, Hasbi., Basri, Syahrul., \& Hamzah, Zainal. 2016. Faktor - Faktor Yang Berhubungan Dengan Keluhan Gangguan Pendengaran Pada Tenaga Kerja Bagian Produksi Pt . Japfa Comfeed. Makassar: UIN Alauddin, 8, 121-134.

Irzal, 2016. Dasar-Dasar Kesehatan dan Keselamatan Kerja. Jakarta: Kencana.

Kementerian Kesehatan, 2016. Peraturan Menteri Kesehatan Republik Indonesia Nomor 70 Tahun 2016 Tentang Standar Dan Persyaratan Kesehatan Lingkungan Kerja Industri. Jurnal Kesehatan Lingkungan Kerja Industri, 23(45), 524.

Kementerian Kesehatan, 2017. Rencana Strategis Kemenkes Tanggulangi Gangguan Pendengaran. Kementrian Kesehatan.

Khakim, Ummi. lanatul, 2011. Hubungan Masa Kerja dengan Nilai Ambang Dengar Tenaga Kerja yang Terpapar Bising pada Bagian Weaving di PT. Triangga Dewi Surakarta. Surakarta: Universitas Sebelas Maret

Marpaung. Dameria Ruth. 2018. Hubungan Intensitas Kebisingan dengan Gangguan Pendengaran pada Tenaga Kerja di Bagian Produksi Pabrik Kelapa Sawit PT. Salim Ivomas Pratama Tbk, Perkebunan Sungai Dua Kabupaten Rokan Hilir Riau Tahun 2017. Riau: Universitas Sumatera Utara

Peraturan Menteri Ketenagakerjaan Republik Indonesia Nomor 5 Tahun 2018 tentang Keselamatan dan Kesehatan Kerja Lingkungan Kerja

Pratama, Reno. Anugerah, 2018. Penerapan Keselamatan Dan Kesehatan Kerja (K3) Di PT Bukit Asam Tanjung Enim Sumatera 
Selatan.Yogyakarta: Universitas Islam Negeri Sunan Kalijaga.

Putri, Hafidah Destiani. 2019. Pengaruh Kebisingan, Umur, Masa Kerja, Dan Pemakaian Apt Terhadap Ambang Pendengaran Pekerja. Surabaya: Poltekkes Kemenkes Surabaya

Putri, Winda.Wahyuni., \& Martiana Tri, 2016. Hubungan Usia dan Masa Kerja dengan Nilai Ambang Dengar Pekerja yang Terpapar Bising di PT. $X$ Sidoarjo. Surabaya: Universitas Airlangga. 5, 173-182.

Qatrunnada, Adani, 2019. Laporan Praktek Pengalaman Belajar Lapangan Pada PT. Indowire Prima Industrindo Tahun Akademik 2019/2020. Surabaya: Poltekkes Kemenkes Surabaya
Rahmawati, Dini, 2015. Faktor-Faktor yang Berhubungan dengan Gangguan Pendengaran Pada Pekerja di Departemen Metal Forming dan Heat Treatment PT. Dirgantara Indonesia (Persero).Jakarta: Universitas Islam Negeri Syarif Hidayatullah

Wibowo, Sapta. Viva, 2012. Gambaran Pajanan Bising dan Fungsi Pendengaran pada Pekerja di Platform ke-5 Kodeco Energy tahun 2011. Depok: Universitas Indoneisa 1-80 